\title{
Determinants of Market Liquidity: Evidence from the Jordanian Stock Market
}

\author{
Mohammad Tayeh ${ }^{1}$ \\ ${ }^{1}$ Department of Finance, School of Business, The University of Jordan, Amman, Jordan \\ Correspondence: Mohammad Tayeh, Finance Department, School of Business, The University of Jordan, \\ Amman 11942, Jordan. Tel: 962-6-535-5000 ext. 24271. E-mail: m.tayeh@ju.edu.jo
}

Received: July 27, 2016

doi:10.5539/ijef.v8n10p48
Accepted: August 11, 2016

Online Published: October 2, 2016

URL: http://dx.doi.org/10.5539/ijef.v8n10p48

\begin{abstract}
Empirical work that investigates how market liquidity varies over time for an emerging market is virtually nonexistent. This paper, therefore, provides evidence from the Amman Stock Exchange (thereafter ASE), on the sources of the times-series variation of market liquidity and its time-series behavior, using a comprehensive sample of stocks over a 15-year time span. Concurrent market movements and market trend variables significantly affect daily changes in market liquidity. There is inconclusive evidence of the impact of market volatility on market liquidity. Market liquidity exhibits both weekly and monthly regularities. Liquidity drops on Sunday but there is inconsistency in its pattern on Thursday. The results of spread regressions show that market liquidity is lower in February and December, while the results of trading activity regressions show that market liquidity is lower in January compared with other months.
\end{abstract}

Keywords: market liquidity, market return, bid-ask spread, trading activity, time-series variation

\section{Introduction}

A large bulk of empirical research in market microstructure has focused on firms-specific liquidity and has examined, in particular, its cross-sectional determinants (see Demsetz, 1968; Tinic, 1972; Benston \& Hagerman, 1974; Branch \& Freed, 1977; Stoll, 1978; Easley et al., 1996 among others). However, the early work on commonality in liquidity by Chordia et al. (2000), Hasbrouck and Seppi (2001) and Huberman and Halka (2001) focuses on market liquidity and diverts the attention of market microstructure literature towards this new area of research (Note 1). Consequently, two areas of research that focus on market liquidity have emerged. The first, concerns the importance of market liquidity on assets pricing, which has been extensively examined in the literature and provides evidence that market liquidity is a priced risk factor that affects stocks returns (Note 2). The other one is interested in identifying the determinants and the time-series behavior of market liquidity, but to date, a few studies have examined market liquidity and the causes of its time-series variation.

Chordia et al. (2001), for example, investigate daily market liquidity for NYSE using measures of spread, depth and trading activity over an 11 year period. They find that market liquidity is affected by market returns, volatility and interest rate variables. They also find that market liquidity drops significantly on Fridays, around holidays and increases prior to the announcement of macroeconomic variables. Fujimoto (2003) examines the impact of macroeconomic variables on market liquidity for NYSE and AMEX. He finds that both inflation and monetary policy have a significant effect on market liquidity. Consistent with Chordia et al. (2001), Fujimoto also finds that daily variation in market liquidity is related to market returns and volatility. In addition, Van Ness et al. (2005) examine the determinants of market liquidity in NASDAQ over the whole sample period and during both bull and bear market. Their results show that market liquidity shows weekly regularities, and that current market returns and interest rate variables affect market liquidity, but they find that market volatility is unrelated to liquidity and macroeconomic announcements have a tiny effect on NASDAQ liquidity.

Moreover, Chordia et al. (2005) investigate the liquidity dynamics across equity and bond markets as well as the impact of monetary policy on liquidity. Consistent with previous studies, their results show that market return (volatility) is negatively (positively) related to market illiquidity and there is a day of the week effect on both markets' liquidity. They also find that relaxed monetary policy results in high stock market liquidity. Following the same line, Goyenko and Ukhov (2009) examine the joint dynamic of stock and bond markets liquidity and monetary policy. They find a linkage between bond and stock market liquidity in addition to monetary policy 
effect on markets liquidity. Recently, Comerton-Forde et al. (2010) provided evidence of the impact of market maker income statement and balance sheet variables on market liquidity. Finally, Tayeh (2010) shifted the attention towards European stock markets and examined the determinants of the time-series variation and the time-series behavior of market liquidity before and after the automation of trading systems in the Vienna, Swiss, Amsterdam, and Frankfurt Stock Exchanges.

The above mentioned studies focus on market liquidity of developed markets, the US markets in particular. Studies on emerging markets that examine the factors that cause the daily variation in market liquidity and analyze its time-series behavior are virtually nonexistent. Therefore, this research provides the first evidence, and extends the literature by investigating this issue on the Jordanian stock market, namely, the ASE, which is one of the emerging markets in the Middle East and North Africa region (thereafter MENA).

Examining liquidity of emerging markets could be very important and could provide useful insights into market participants including exchange regulators and investors. One interesting characteristic of the structure of emerging markets, especially in the MENA region, is that they have no market makers. This results in a lack of liquidity provision, and thus, market liquidity represents a major concern to market participants. Consequently, lower liquidity in emerging markets, compared with developed markets, will result in significant returns erosion. That is, the liquidity effects in emerging markets is considered to be stronger than that in developed markets (Lesmond, 2005; Bekaert et al., 2007), and its variation could represent a systematic risk that could have an effect across stocks' liquidity and returns. This stimulates the investigation of the sources of the time-series variation in market liquidity in emerging markets. Furthermore, the research on MENA markets is almost neglected (Lagoarde-Segot \& Lucey, 2008): therefore, any empirical research into these markets will be considered as a valuable addition to the literature, and will enhance our knowledge and understanding of the factors that affect market liquidity in these markets.

The analysis of the determinants of market liquidity and its time-series variation in the ASE is carried out over a 15-year sample period, using daily measures of market liquidity; quoted spread, proportional quoted spread, effective spread from Roll (1984), modified effective spread, high-low spread estimator developed by Corwin and Schultz (2012), turnover rate, volume, trading value and number of trades. The time-series market liquidity is constructed as a cross-sectional average of a liquidity measure for all stocks traded on a particular day.

Following the methodology of Chordia et al. (2001) the results show that market liquidity is related to concurrent market conditions; there is an improvement in market liquidity when the market performs well and vice versa. There is an impact of market trend variables on market liquidity. However, the results regarding the recently rising market are inconclusive. That is, the recently rising market coefficient is positively related to the quoted and proportional quoted spread, but it is negatively related with other spread measures. Also, a recently rising market is negatively related to the turnover rate but is positively related to trading value. A recently falling market is associated with an increase in market liquidity. Consistent with the market microstructure argument, the majority of the results show that recent market volatility is negatively related to market liquidity. Finally, the results provide evidence of the existence of distinct weekly and monthly seasonality. That is, market liquidity drops significantly on Sundays as well as in both February and December.

The rest of this paper is organized as follows: Section 2 describes the data and explains liquidity measures, Section 3 presents the time-series properties of market liquidity, Section 4 discusses the empirical results, and Section 5 presents the conclusion.

\section{Data}

The reliability of the results for the determinants and time-series behavior of market liquidity requires a construction of market liquidity series that spans a long sample period. Therefore, daily data have been used to measure liquidity rather than high frequency data, which are not available for emerging markets even for a short time period. The daily data for this study are obtained from ASE for all firms during a 15-year sample period; from January 1, 2000 to December 31, 2014. For each stock included in the sample, the data include closing price, high and low prices, best bid and ask prices, trading volume, number of shares outstanding, and number of trades. Data on stock market price index are collected to calculate market return variables. Initial inspection of the data uncovered some recording errors such as multiple trading symbols for a company, duplication in some data records, and errors in the date. These errors were either deleted or corrected.

\subsection{Measures of Liquidity}

Liquidity is an evasive and multidimensional concept that cannot be measured precisely. It has several dimensions such as immediacy, width, depth, and price resilience, which cannot be captured in a single measure. 
On the other hand, each liquidity measure available in literature captures at least one of its dimensions. This research, therefore, employs some liquidity measures that are frequently and widely used in the market microstructure literature.

First, Quoted Spread: is measured as the difference between ask and bid prices. Demsetz (1968) argues that bid-ask spread reflects the price for immediate trading. It is widely used as a liquidity measure in most of the literature. It is given by:

$$
Q B A S_{i, t}=P A_{i, t}-P B_{i, t}
$$

Where $Q B A S_{i, t}$ the quoted bid-ask spread for stock $i$ at day $t, P A_{i, t}$ and $P B_{i, t}$ are the ask price and bid price for stock $i$ at day $t$.

Second, Proportional Quoted Spread: is computed as the percentage of the difference between ask and bid price to the midpoint of the quoted bid-ask spread.

$$
P Q B A S_{i, t}=\frac{P A_{i, t}-P B_{i, t}}{\left(\frac{P A_{i, t}+P B i, t}{2}\right)}
$$

Where $P Q B A S_{i, t}$ is the proportional quoted bid-ask spread for stock $i$ at day $t$.

Third, Roll Measure (i.e. Effective Spread): Roll (1984) introduces a measure of effective spread that depends on measuring the serial covariance among daily changes in stock prices. This covariance results from the bouncing of stock's price between the bid and ask prices. This measure is estimated as follows:

$$
\text { EFFS }_{i, t}=2 \sqrt{-\operatorname{cov}\left(\Delta P_{i, t}, \Delta P_{i, t-1}\right)}
$$

Where, $E F F S_{i, t}$ is the effective spread for stock $i$ at day $t, P_{i, t}$ and $P_{i, t-1}$ are the observed price for stock $i$ on day $t$ and $t-1$ respectively.

Fourth, Modified Roll (i.e. modified Effective Spread): as in equation (3), Roll measure is undefined when there is a positive serial covariance. Therefore, a modified version of this measure is used through replacing the positive values of covariance with zeros (see Goyenko et al., 2009). It is estimated as follows:

$$
\operatorname{MEFFS}_{i, t}=\left\{\begin{array}{c}
2 \sqrt{-\operatorname{cov}\left(\Delta P_{i, t}, \Delta P_{i, t-1}\right)} \text { when } \operatorname{cov}\left(\Delta P_{t}, \Delta P_{t-1}\right)<0 \\
0 \quad \text { when } \operatorname{cov}\left(\Delta P_{t}, \Delta P_{t-1}\right) \geq 0
\end{array}\right.
$$

Where, MEFFS $S_{i, t}$ is modified effective spread for stock $i$ at day $t$.

Fifth, High-low spread estimator: recently, Corwin and Schultz (2012) developed a simple way to measure bid-ask spread using daily data for high and low prices. Corwin and Schultz argue that this measure is easy to use and that it captures both the cross-section and time-series variation in spreads of individual firms, and that it broadly captures liquidity more than the bid-ask spread itself. This measure is estimated as follows:

$$
\begin{gathered}
\text { HL Spread }=\frac{2\left(e^{\alpha}-1\right)}{1+e^{\alpha}} \\
\alpha=\frac{(\sqrt{2 \beta}-\sqrt{\beta})}{(3-2 \sqrt{2})}-\sqrt{\frac{\gamma}{3-2 \sqrt{2}}} \\
\beta=\left(\operatorname{Ln}\left(\frac{H_{t}}{L_{t}}\right)\right)^{2}+\left(\operatorname{Ln}\left(\frac{H_{t+1}}{L_{t+1}}\right)\right)^{2} \\
\gamma=\left(\operatorname{Ln}\left(\frac{H_{t, t+1}}{L_{t, t+1}}\right)\right)^{2}
\end{gathered}
$$

Where, $L_{t}$ and $H_{t}$ are the daily low and high prices.

Sixth, Volume: the total number of shares that are traded during the day.

Seventh, Turnover: Turnover reflects trading frequency, but it cannot capture the trading cost. However, it is observable when liquidity cannot be observed directly. It is an intuitive measure of liquidity and it is attractive and easy to calculate using daily data (see Datar et al., 1998; Chen, 2005). It is calculated as follows:

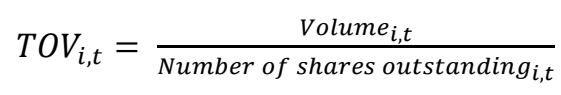


Table 1. Summary statistics for market liquidity

\begin{tabular}{lcccccc}
\hline Variable & Mean & Median & Std. Dev. & CV & Minimum & Maximum \\
\hline QBAS & 0.153 & 0.119 & 0.127 & 0.833 & 0.023 & 1.626 \\
PQBAS & 0.120 & 0.097 & 0.108 & 0.904 & 0.013 & 1.334 \\
EFFS & 0.023 & 0.020 & 0.013 & 0.563 & 0.004 & 0.227 \\
MEFFS & 0.014 & 0.013 & 0.006 & 0.427 & 0.003 & 0.039 \\
HL Spread & 0.021 & 0.020 & 0.005 & 0.263 & 0.000 & 0.048 \\
TOV & 0.006 & 0.005 & 0.033 & 5.934 & 0.000 & 1.955 \\
Volume (000's) & 87.458 & 66.115 & 968.227 & 11.071 & 2.221 & 58617.004 \\
Tvalue (JD 000) & 147.165 & 87.173 & 193.160 & 1.313 & 5.448 & 8216.950 \\
NoTrades & 44.936 & 37.517 & 25.516 & 0.568 & 5.844 & 137.492 \\
\hline
\end{tabular}

Note. This table represents the time series summary statistics for market liquidity variables. Market liquidity series are constructed as the cross-sectional average of the liquidity of all stocks for each trading day in the sample. The sample period extends from January 2000 to December 2014, with 3689 trading days. QBAS is the quoted bid-ask spread, PQBAS is the percentage quoted bid-ask spread, EFFS, is the Roll (1984) measure of effective spread, MEEFS is the modified Roll measure of effective spread, HL Spread, is the High-low spread estimator developed by Corwin and Schultz (2012), TOV, is the turnover rate, Volume is the total shares traded during the day, Tvalue is the trading value (the dinar volume, which is the number of shares traded multiplied by the closing price), NoTrades is the number of trades. Std. Dev. refers to the standard deviation and CV refers to coefficient of variation.

Where, $T O V_{i, t}$ is the turnover ratio for stock $i$ at day $t$, Volume $e_{i, t}$ is the stock's number of shares traded in day $t$.

Eighth, Trading Value: the total Dinar volume (the local currency of Jordan) during the day, which is calculated as follows:

$$
\text { TVALUE }_{i, t}=\text { Volume }_{i, t} \times P_{i, t}
$$

Where, $P_{t}$ is the closing price of the stock $i$ at day $t$.

Ninth, Number of Trades: the total number of transactions during the day.

Although the liquidity measures discussed above, are defined on a firm-specific level, the investigation undertaken in this study focuses on market liquidity series. These series are constructed as a cross-sectional average of liquidity of all individual firms in a particular trading day. To avoid confusion, the acronyms of firm-specific liquidity variables are retained for market liquidity.

\section{Properties of Market Liquidity}

\subsection{Levels of Market Liquidity}

The descriptive statistics of the levels, not the percentage changes, of market liquidity are presented in Table 1. All market liquidity variables show considerable variation over time, but spread measures show less variation than trading activity measures, turnover rate, volume and trading value, as shown by the coefficients of variation. According to Chordia et al. (2001), this may result from the discrete nature of bid and ask prices. Most market liquidity variables show insignificant skewness in their daily distribution, as the medians are almost close to the means. Moreover, over the 15-year period, the average of quoted spread and proportional quoted spread is higher than the average of effective spread and modified effective spread. These averages, however, are greater than those reported by Chordia et al. (2001) for NYSE and Van Ness et al. (2005) for NASDAQ, which confirms the fact that ASE is an illiquid market (Note 3). However, the daily trading volume in ASE ranges from 2.221 to almost 58617 thousand shares traded with the daily number of trades ranges from 5.844 to 137.492 .

\subsection{Changes in Market Liquidity}

Panel A of Table 2 shows the descriptive statistics for the daily absolute values of the percentage changes in market liquidity variables. The average of absolute daily percentage changes in trading activity measures namely, turnover rate, volume and trading value, ranges from more than $50 \%$ to approximately $114 \%$. In contrast, the average of daily changes in spread measures ranges from $2.6 \%$ to $41.4 \%$. This confirms the results of coefficients of variation reported in Table 1, which show that trading activity measures are more volatile than other variables. 
Table 2. Summary statistics and correlation coefficients for the percentage changes in market liquidity

\begin{tabular}{|c|c|c|c|c|c|c|c|c|}
\hline \multicolumn{9}{|c|}{ Panel A: Summary statistics for the absolute values of the daily percentage changes in market liquidity } \\
\hline \multicolumn{3}{|l|}{ Variable } & \multicolumn{2}{|l|}{ Mean } & \multicolumn{2}{|l|}{ Median } & \multicolumn{2}{|c|}{ Std. Dev. } \\
\hline \multicolumn{2}{|l|}{$|\Delta \mathrm{QBAS}|$} & \multicolumn{3}{|c|}{0.373} & \multicolumn{2}{|l|}{0.275} & \multicolumn{2}{|c|}{0.41} \\
\hline \multicolumn{2}{|l|}{$|\triangle \mathrm{PQBAS}|$} & \multicolumn{3}{|c|}{0.414} & \multicolumn{2}{|l|}{0.274} & \multicolumn{2}{|c|}{0.579} \\
\hline \multicolumn{2}{|l|}{$|\triangle \mathrm{EFFS}|$} & \multicolumn{3}{|c|}{0.026} & \multicolumn{2}{|l|}{0.012} & \multicolumn{2}{|c|}{0.08} \\
\hline \multicolumn{2}{|l|}{$|\triangle \mathrm{MEFFS}|$} & \multicolumn{3}{|c|}{0.027} & \multicolumn{2}{|l|}{0.012} & \multicolumn{2}{|c|}{0.068} \\
\hline \multicolumn{2}{|l|}{$\mid \Delta \mathrm{HL}$ Spread $\mid$} & \multicolumn{3}{|c|}{0.134} & \multicolumn{2}{|l|}{0.078} & \multicolumn{2}{|c|}{0.84} \\
\hline \multicolumn{2}{|l|}{$|\Delta \mathrm{TOV}|$} & \multicolumn{3}{|c|}{0.628} & \multicolumn{2}{|l|}{0.167} & \multicolumn{2}{|c|}{21.564} \\
\hline \multicolumn{2}{|l|}{$\mid \Delta$ Volume $\mid$} & \multicolumn{3}{|c|}{1.136} & \multicolumn{2}{|l|}{0.168} & \multicolumn{2}{|c|}{49.389} \\
\hline \multicolumn{2}{|l|}{$\mid \Delta$ Tvalue $\mid$} & & 0.532 & & 0.191 & & & \\
\hline $\mid \Delta$ NoTrades $\mid$ & & & 0.131 & & 0.104 & & & \\
\hline Panel B: Corr & of daily $\mathrm{p}$ & ntage chan & $\mathrm{n}$ market $\mathrm{l}$ & & & & & \\
\hline Variable & $\triangle \mathrm{QBAS}$ & $\triangle \mathrm{PQBAS}$ & $\triangle \mathrm{EFFS}$ & $\triangle \mathrm{MEFFS}$ & $\Delta$ HL Spread & $\Delta \mathrm{TOV}$ & $\Delta$ Volume & $\Delta$ Tvalue \\
\hline$\triangle \mathrm{PQBAS}$ & 0.701 & & & & & & & \\
\hline$\triangle \mathrm{EFFS}$ & 0.001 & 0.003 & & & & & & \\
\hline$\triangle \mathrm{MEFFS}$ & -0.033 & -0.016 & 0.260 & & & & & \\
\hline$\Delta \mathrm{HL}$ Spread & -0.027 & -0.046 & -0.002 & 0.053 & & & & \\
\hline$\triangle \mathrm{TOV}$ & -0.031 & -0.024 & -0.006 & -0.009 & 0.001 & & & \\
\hline$\Delta$ Volume & 0.007 & -0.014 & -0.006 & -0.009 & 0.001 & 0.999 & & \\
\hline$\Delta$ Tvalue & 0.009 & -0.006 & -0.005 & -0.009 & 0.001 & 0.999 & 0.999 & \\
\hline$\Delta$ NoTrades & -0.047 & -0.052 & 0.025 & -0.001 & -0.025 & 0.018 & 0.016 & 0.024 \\
\hline
\end{tabular}

Note. Panel A in this table shows the time-series summary statistics for the absolute values of the daily percentage changes in market liquidity variables. Market liquidity variables are as described in table 1 . Std. Dev. refers to the standard deviation. Panel B shows the correlation coefficients among the daily percentage changes in market liquidity. $\Delta$ refers to the daily percentage change in market liquidity.

Furthermore, Panel B of Table 2 reports the correlation coefficients among the percentage changes in market liquidity variables. Although the correlations among the percentage changes in market liquidity variables are very low, the correlations between the percentage quoted spread and modified effective spread with all trading activity measures are negative as expected. Except number of trades, other trading activity measures are also negatively correlated with effective spread, but they are positively correlated with HL spread measure.

Table 3 shows the results of autocorrelation for the percentage change in market liquidity series for five lags (i.e. five trading days). Every spread series shows a negative first-order autocorrelation that is statistically significant at $1 \%$ level of significance. This is consistent with the results of Chordia et al. (2001) and Van Ness et al. (2005), but some of spread series in ASE show a negative autocorrelation for a higher order. For example, the daily percentage changes in proportional quoted spread, quoted spread, and HL spread show, respectively, negative fourth order and fifth order autocorrelation. Further, all trading activity series also show significant negative first order autocorrelation, and show negative autocorrelation for longer lags, up to four and five lags. This may suggest that persistence is represented in market liquidity series, which means that negative shocks of liquidity create lower liquidity in the future (Bali et al., 2014).

Table 3. Autocorrelations of market liquidity

\begin{tabular}{|c|c|c|c|c|c|}
\hline \multicolumn{6}{|c|}{ Lags order in daily observations } \\
\hline & $\mathrm{AR}(1)$ & $\mathrm{AR}(2)$ & $\mathrm{AR}(3)$ & $\mathrm{AR}(4)$ & $\mathrm{AR}(5)$ \\
\hline$\triangle \mathrm{QBAS}$ & $-0.490^{\mathrm{a}}$ & $-0.295^{\mathrm{a}}$ & $-0.162^{\mathrm{a}}$ & $-0.101^{\mathrm{a}}$ & $-0.042^{b}$ \\
\hline$\triangle \mathrm{PQBAS}$ & $-0.398^{\mathrm{a}}$ & $-0.242^{\mathrm{a}}$ & $-0.114^{\mathrm{a}}$ & $-0.064^{\mathrm{a}}$ & 0.007 \\
\hline$\triangle \mathrm{EFFS}$ & $-0.139^{\mathrm{a}}$ & -0.001 & 0.009 & -0.020 & -0.011 \\
\hline$\triangle \mathrm{MEFFS}$ & $-0.161^{\mathrm{a}}$ & -0.025 & -0.018 & 0.006 & $-0.037^{\mathrm{b}}$ \\
\hline$\Delta$ HL Spread & $-0.576^{\mathrm{a}}$ & $-0.406^{\mathrm{a}}$ & $-0.275^{\mathrm{a}}$ & $-0.187^{\mathrm{a}}$ & $-0.081^{\mathrm{a}}$ \\
\hline$\Delta \mathrm{TOV}$ & $-0.441^{\mathrm{a}}$ & $-0.279^{\mathrm{a}}$ & $-0.210^{\mathrm{a}}$ & $-0.128^{\mathrm{a}}$ & $-0.043^{\mathrm{b}}$ \\
\hline$\Delta$ Volume & $-0.439^{\mathrm{a}}$ & $-0.246^{\mathrm{a}}$ & $-0.158^{\mathrm{a}}$ & $-0.111^{\mathrm{a}}$ & -0.027 \\
\hline$\Delta$ Tvalue & $-0.431^{\mathrm{a}}$ & $-0.265^{\mathrm{a}}$ & $-0.180^{\mathrm{a}}$ & $-0.120^{\mathrm{a}}$ & $-0.032^{\mathrm{c}}$ \\
\hline$\Delta$ NoTrades & $-0.349 a$ & $-0.219 a$ & $-0.167 \mathrm{a}$ & $-0.122 \mathrm{a}$ & -0.022 \\
\hline
\end{tabular}

Note. This table reports the coefficients of autocorrelation for the daily percentage changes in market liquidity variables that are defined in Table 1. $\Delta$ refers to the daily percentage change in market liquidity. a, b, and c refer to significance level at $1 \%, 5 \%$, and $10 \%$, respectively. 
This may also be an indication of the existence of weekly regularities in market liquidity. However, according to Chordia et al. (2001), the significant negative autocorrelation shown in most market liquidity series could be as a result of stationarity that may exist in all of these series, but Van Ness et al. (2005) suggest that these negative autocorrelations are consistent with the reversion of the mean of different trading metrics (Note 4).

\section{Empirical Results of the Determinants of Market Liquidity}

The goal of this research is to examine the different possible determinants that may affect the changes in market liquidity for ASE. Therefore, the time-series of daily percentage changes in market liquidity are regressed on a set of variables that include market variables and dummies for the day of the week and for the month of the year. This approach, to some extent, is similar to that applied by Chordia et al. (2001) and Van Ness et al. (2005). The regression model is as follows:

$$
\operatorname{MKTLI}_{m, t}=\alpha_{t}+\sum_{n=1}^{5} \beta_{m, n} X_{n, m, t}+\sum_{n=1}^{4} \gamma_{m, n} \text { Day }_{n, t}+\sum_{n=1}^{11} \delta_{m, n} \text { Month }_{n, t}+\epsilon_{m, t}
$$

Where $M K T L I Q_{m, t}$ is the daily percentage change in market liquidity on day $t$, which is represented by one of the nine different liquidity measures. $X_{m, t}$ is a vector of market control variables, which includes the following variables: up (down) markets measured as daily return of the index if it is positive (negative) and zero otherwise, which reflects the impact of current market movements on market liquidity; recent rising (falling) market movements that are measured as the daily index return over the past five trading days if it is positive (negative) and zero otherwise; market volatility measured as the average of the absolute value of the daily index return over the past five trading days. Day $y_{n, t}$ is the day of the week dummies for trading days from Sunday through Wednesday that assigns the value of 1 if the trading day is Sunday, Monday, Tuesday, Wednesday and zero otherwise. Month $h_{n, t}$ is month of the year dummies for February through December and it assigns the value of 1 if the trading day falls in one of these eleven months and zero otherwise. These possible determinates of market liquidity are selected based on the rationale proposed by Chordia et al. (2001). However, interest rate variables (i.e. short term interest rate, term spread and quality spread) are not included in the analysis because short sale is not allowed in ASE as well as there being no active bond market.

Based on the evidence of negative dependence reported in Table 3, the results of our regression model could suffer from the presence of the autocorrelation problem. Therefore, the time-series regression equation (8) is estimated using the GMM estimation method with adjustment for heteroscedasticity and auto-correlation using Newey-West standard error correction. We also re-estimate equation (8) using the Cochrane Orcutt iterative correction procedure to correct for first order autocorrelation. The results are qualitatively similar, but, to conserve some space, they are not reported here.

Panel A of Table 4 shows the results of the time-series regression model, where the market return variables, market volatility, and day-of-the-week dummies are used as explanatory variables. The results show that there is asymmetric response of quoted spread, proportional quoted spread and modified effective spread to up and down market conditions. That is, both quoted spread and proportional quoted spread decrease (increase) during up (down) market conditions as expected. During down market conditions, investors are expected to avoid trading through quoting higher bid-ask spread, which is the opposite to how they are expected to react during up market conditions. This is consistent with the results of Chordia et al. (2001), Fujimoto (2003), Van Ness et al. (2005) and Tayeh (2010). However, the modified effective spread shows the opposite response to the up and down market. It increases (decreases) in up (down) market. Also, effective spread and HL spread decrease in down market. The reason why effective spread measures and HL spread responded in that way to up and down market conditions is likely to be due to the expected behavior of prices during these market conditions, as these measures are constructed from daily prices.

Trading activities measures also show asymmetric response to the both up and down markets. The coefficients of up and down markets in all trading activity measures are positive and statistically significant at $5 \%$ level of significance or better. This means that during up and down market conditions there is, respectively, an increase and decrease in turnover rate, share volume, trading value and number of trades. This implies that trading activities of investors are consistent with the market conditions; they increase during market improvement and vice versa. The asymmetric response in trading activities under different conditions of the market is inconsistent with the results of Chordia et al. (2001), Van Ness et al. (2005), and Tayeh (2010), who find that trading activities increase during up and down markets. But this is consistent with Fujimoto (2003) who finds a positive relationship between market liquidity and market performance. All in all, the results show that market liquidity is associated with market conditions; it increases when market performance is good and decreases during periods of bad performance of the market. 
With regard to the market trend variables, recently rising and falling markets, it is expected that market liquidity will increase following the increase in the past market moves and vice versa, which may be due to the contrarian, momentum or overconfidence theories (see, e.g., Chordia et al., 2001; Gervais \& Odean, 2001; Statman et al., 2006; Glaser \& Weber, 2009). However, our results provide inconclusive evidence. The coefficient of recently rising market is statistically positive in quoted and proportional quoted spread, but is statistically negative in other spread measures. This indicates that a recently rising market is related to a decrease in effective spread measures and HL spread, which is expected, but, surprising, it is associated with an increase in both quoted and proportional quoted spread. Also, a recently rising market results in a drop in turnover rate while it results in an increase in trading value. Given the result for turnover rate, the increase in trading value may be because of the increase in prices during a recently rising market. Further, the results show that a recently falling market is associated with an increase in market liquidity as indicated by its significantly positive and negative coefficient, respectively, in proportional quoted spread regression and trading activity regressions. This may imply that investors show more confidence about their information following a recently falling market and thus trade more frequently, which is, surprisingly, unexpected. In contrast, Chordia et al. (2001) and Tayeh (2010) find that market liquidity decreases during a recently falling market, whereas Van Ness et al. (2005) find no relation between market trend variables and market liquidity.

It is well documented in the market microstructure literature that volatility is negatively related to individual stock liquidity (see, e.g., Tinic, 1972; Benston \& Hagerman, 1974; Stoll, 1978; Menyah \& Paudyal, 1996), therefore, we expect the same impact will be at market level. Our results are consistent with this argument, as the estimated coefficient of market volatility is significantly positive in effective spread, modified effective spread and HL spread regressions and negative in trading value regression. This is in the same line as the findings of Chordia et al. (2001), Huberman and Halka (2001), Fujimoto (2003), Chordia et al. (2005) and Tayeh (2010). However, the results of both quoted spread and proportional quoted spread are inconsistent, as the market volatility is associated with an increase in market liquidity; the coefficient of market volatility estimated in these regressions is negatively significant at $1 \%$ level of significance. This is consistent with the findings of Chordia et al. (2001) who also find that NYSE liquidity increases with volatility. This may be due to the fact that investors quote low bid-ask prices to attract more investors to rebalance their portfolios while the market is highly volatile (See, e.g., Chordia et al., 2001; Tayeh, 2010).

The results of the day-of-the-week effect show that market liquidity drop significantly at the beginning of the week. The estimated coefficient of Sunday is significantly positive in effective spread and HL spread regressions and significantly negative in trading activity regressions. This may imply that the level of information asymmetry could be high at the beginning of the week relative to other days of the week. Further, the results of trading activity regressions show that market liquidity declines on Monday and Wednesday: their coefficients are significantly negative. However, the results of spread regressions show a contradiction in the behavior of market liquidity on Tuesday. The significantly negative coefficient of Tuesday in quoted and proportional quoted spread shows an increase in liquidity, while the significantly positive coefficient in modified effective spread and HL spread shows a drop in market liquidity. Finally, the constant that is supposed to pick up the effect of Thursday also shows inconsistent behavior in market liquidity. The constant is positive and statistically significant at $1 \%$ level of significance in quoted spread, proportional quoted spread and all trading activity regressions. This may imply that investors would like to trade more at the end of the week even if the quoted bid-ask spread is high. All in all, the results of the day-of-the-week dummies show that liquidity in ASE shows weekly regularities, which is consistent with the results of the previous studies such as Chordia et al. (2001), Chordia et al. (2005), Van Ness et al. (2005) and Tayeh (2010).

Furthermore, to examine whether market liquidity exhibits monthly regularities, we re-estimated equation (8) using, as explanatory variables, market returns variables, market volatility, and month of the year dummies for February through December. The results are reported in Panel B of table 4. The results of market variables are qualitatively and quantitatively similar to those reported in panel $\mathrm{A}$. The results of estimated coefficients of the month of the year dummies show that there is a monthly seasonality in market liquidity. The results of quoted spread regression show that market liquidity is lower in March, April, September, October and December; their estimated coefficients are significantly positive at $10 \%$ level of significance or better. However, the coefficient of December and the constant, which is picking up the effect of January, show lower market liquidity compared with the rest of the year. In proportional quoted spread regression, the results also show lower market liquidity in February, March, June, October and December, but market liquidity is lower in February and December relative to other months. In addition, the coefficient of November in number of trades regression is statistically negative, which means that market liquidity is lower during this month. However, the constant in all trading activity 
measures shows that market liquidity is higher in January than any other month.

Finally, Panel $\mathrm{C}$ of Table 4 reports the results of re-estimating the equation (8) using all explanatory variables; market returns variables, market volatility, day-of-the-week dummies, and month of the year dummies for February through December. Again the results are qualitatively and quantitatively similar to those reported in the previous two panels.

The values of adjusted $R^{2}$, in all panels, are not very impressive, which may be due to non-inclusion of some other variables that could be a possible determinant of market liquidity, that is, due to omitted variables. Furthermore, the lower predictive power could be due to the inclusion of market return variables that could be considered to be publicly available information (see Chordia et al., 2002).

Table 4. Time-series regressions

\begin{tabular}{|c|c|c|c|c|c|c|c|c|c|}
\hline \multicolumn{10}{|c|}{$\begin{array}{l}\text { Panel A: The time-series regression results using market return variables, market volatility and day-of-the-week dummies as explanatory } \\
\text { variables }\end{array}$} \\
\hline MKT Liq. Var. & $\Delta \mathrm{QBAS}$ & $\triangle \mathrm{PQBAS}$ & $\triangle \mathrm{EFFS}$ & $\triangle$ MEFFS & $\Delta$ HL Spread & $\Delta \mathrm{TOV}$ & $\Delta$ Volume & $\Delta$ Tvalue & $\Delta$ NoTrades \\
\hline \multicolumn{10}{|l|}{ Exp. Var. } \\
\hline Constant & $0.112^{\mathrm{a}}$ & $0.105^{\mathrm{a}}$ & -0.003 & -0.003 & -0.002 & $0.063^{\mathrm{a}}$ & $0.064^{\mathrm{a}}$ & $0.080^{\mathrm{a}}$ & $0.028^{\mathrm{a}}$ \\
\hline $\mathrm{MKT}_{P o s}$ & $-0.134^{a}$ & $-0.376^{\mathrm{b}}$ & -0.025 & $0.097^{\mathrm{a}}$ & -0.010 & $0.196^{\mathrm{b}}$ & $0.326^{\mathrm{a}}$ & $0.388^{\mathrm{b}}$ & $0.287^{\mathrm{a}}$ \\
\hline $\mathrm{MKT}_{N e g}$ & $-16.379^{\mathrm{a}}$ & $-25.815^{a}$ & $1.007^{\mathrm{a}}$ & $1.196^{\mathrm{a}}$ & $3.128^{\mathrm{a}}$ & $4.548^{\mathrm{a}}$ & $4.427^{\mathrm{a}}$ & $3.822^{\mathrm{a}}$ & $1.728^{\mathrm{a}}$ \\
\hline $\mathrm{MA5MKT}_{P o s}$ & $9.110^{\mathrm{a}}$ & $9.704^{\mathrm{a}}$ & $-1.162^{\mathrm{a}}$ & $-1.403^{\mathrm{a}}$ & $-2.943^{\mathrm{a}}$ & $-1.343^{\mathrm{c}}$ & -0.920 & $1.767^{\mathrm{c}}$ & -0.062 \\
\hline $\mathrm{MA5MKT}_{N e g}$ & 3.973 & $11.983^{\mathrm{a}}$ & 0.334 & 0.409 & -0.151 & $-2.704^{\mathrm{c}}$ & -2.579 & $-4.874^{\mathrm{b}}$ & 0.206 \\
\hline MKTVol & $-9.072^{\mathrm{a}}$ & $-7.752^{\mathrm{a}}$ & $1.107^{\mathrm{a}}$ & $1.279^{\mathrm{a}}$ & $3.064^{\mathrm{a}}$ & 1.146 & 0.710 & $-1.942^{\mathrm{c}}$ & -0.036 \\
\hline Sunday & -0.007 & -0.045 & $0.011^{\mathrm{b}}$ & 0.008 & $0.018^{\mathrm{b}}$ & $-0.051^{\mathrm{a}}$ & $-0.058^{\mathrm{a}}$ & $-0.064^{\mathrm{a}}$ & $-0.036^{\mathrm{a}}$ \\
\hline Monday & -0.018 & -0.031 & 0.008 & 0.008 & $-0.026^{\mathrm{a}}$ & $-0.029^{c}$ & -0.005 & -0.010 & 0.003 \\
\hline Tuesday & $-0.080^{\mathrm{a}}$ & $-0.087^{\mathrm{a}}$ & 0.005 & $0.012^{\mathrm{b}}$ & $0.029^{\mathrm{a}}$ & -0.008 & -0.013 & -0.007 & -0.004 \\
\hline Wednesday & -0.032 & -0.001 & 0.008 & 0.006 & 0.005 & $-0.039^{b}$ & $-0.032^{\mathrm{c}}$ & -0.026 & $-0.016^{\mathrm{c}}$ \\
\hline$R^{2}$ & 0.045 & 0.082 & 0.005 & 0.007 & 0.033 & 0.015 & 0.015 & 0.014 & 0.019 \\
\hline Adj $R^{2}$ & 0.042 & 0.080 & 0.003 & 0.005 & 0.031 & 0.013 & 0.013 & 0.011 & 0.016 \\
\hline \multicolumn{10}{|c|}{$\begin{array}{l}\text { Panel B: The time-series regression results using market return variables, market volatility and month of the year dummies as explanatory } \\
\text { variables }\end{array}$} \\
\hline MKT Liq. Var. & $\triangle \mathrm{QBAS}$ & $\triangle \mathrm{PQBAS}$ & $\triangle \mathrm{EFFS}$ & $\triangle \mathrm{MEFFS}$ & $\Delta$ HL Spread & $\Delta \mathrm{TOV}$ & $\Delta$ Volume & $\Delta$ Tvalue & $\Delta$ NoTrades \\
\hline \multicolumn{10}{|l|}{ Exp. Var. } \\
\hline Constant & $0.053^{\mathrm{a}}$ & 0.027 & -0.002 & 0.001 & -0.001 & $0.033^{\mathrm{a}}$ & $0.029^{\mathrm{a}}$ & $0.058^{\mathrm{a}}$ & $0.022^{\mathrm{a}}$ \\
\hline $\mathrm{MKT}_{P o s}$ & $-0.120^{\mathrm{a}}$ & $-0.384^{b}$ & 0.022 & $0.099^{\mathrm{a}}$ & 0.000 & $0.178^{\mathrm{b}}$ & $0.300^{\mathrm{a}}$ & $0.357^{\mathrm{b}}$ & $0.269^{\mathrm{a}}$ \\
\hline $\mathrm{MKT}_{N e g}$ & $-16.217^{\mathrm{a}}$ & $-25.425^{\mathrm{a}}$ & $0.940^{\mathrm{a}}$ & $1.139^{\mathrm{a}}$ & $3.209^{\mathrm{a}}$ & $4.672^{\mathrm{a}}$ & $4.455^{\mathrm{a}}$ & $3.900^{\mathrm{a}}$ & $1.680^{\mathrm{a}}$ \\
\hline MA5MKT $_{P o s}$ & $8.867^{\mathrm{a}}$ & $9.529^{\mathrm{a}}$ & $-1.106^{\mathrm{a}}$ & $-1.363^{\mathrm{a}}$ & $-3.011^{\mathrm{a}}$ & $-1.421^{\mathrm{c}}$ & -0.833 & $1.819^{\mathrm{c}}$ & -0.007 \\
\hline $\mathrm{MA5MKT}_{N e g}$ & 4.238 & $12.044^{\mathrm{a}}$ & 0.328 & 0.420 & -0.101 & $-2.798^{\mathrm{c}}$ & -2.703 & $-5.031^{\mathrm{b}}$ & 0.122 \\
\hline MKTVol & $-8.782^{\mathrm{a}}$ & $-7.486^{\mathrm{a}}$ & $1.045^{\mathrm{a}}$ & $1.241^{\mathrm{a}}$ & $3.134^{\mathrm{a}}$ & $1.253^{\mathrm{c}}$ & 0.679 & $-1.964^{c}$ & -0.080 \\
\hline February & 0.037 & $0.071^{\mathrm{b}}$ & 0.000 & -0.001 & 0.006 & -0.003 & 0.014 & -0.006 & -0.007 \\
\hline March & $0.044^{\mathrm{c}}$ & $0.048^{c}$ & 0.006 & 0.001 & -0.002 & 0.005 & 0.017 & 0.018 & 0.004 \\
\hline April & $0.040^{c}$ & 0.035 & 0.006 & 0.004 & 0.010 & 0.013 & 0.005 & -0.011 & -0.007 \\
\hline May & 0.027 & 0.025 & -0.001 & -0.002 & 0.003 & 0.013 & 0.015 & 0.017 & -0.003 \\
\hline June & 0.033 & $0.063^{\mathrm{c}}$ & 0.005 & 0.002 & 0.010 & 0.002 & 0.006 & -0.013 & -0.005 \\
\hline July & 0.002 & 0.049 & 0.005 & 0.004 & 0.001 & 0.001 & 0.019 & 0.002 & 0.000 \\
\hline August & 0.014 & 0.048 & 0.009 & 0.009 & 0.010 & 0.008 & 0.010 & -0.014 & -0.006 \\
\hline September & $0.040^{c}$ & 0.030 & 0.006 & 0.002 & 0.004 & 0.005 & 0.015 & 0.001 & -0.005 \\
\hline October & $0.038^{c}$ & $0.062^{\mathrm{c}}$ & 0.006 & 0.007 & 0.005 & 0.009 & 0.020 & 0.005 & -0.004 \\
\hline November & 0.019 & 0.042 & 0.003 & 0.000 & 0.008 & -0.002 & 0.012 & 0.003 & $-0.014^{\mathrm{c}}$ \\
\hline December & $0.077^{\mathrm{a}}$ & $0.074^{\mathrm{b}}$ & 0.007 & 0.002 & -0.002 & 0.000 & 0.024 & 0.003 & -0.011 \\
\hline$R^{2}$ & 0.043 & 0.080 & 0.005 & 0.007 & 0.017 & 0.011 & 0.010 & 0.009 & 0.011 \\
\hline Adj $R^{2}$ & 0.038 & 0.076 & 0.000 & 0.002 & 0.013 & 0.006 & 0.006 & 0.005 & 0.007 \\
\hline
\end{tabular}


Table 4. continued

\begin{tabular}{|c|c|c|c|c|c|c|c|c|c|}
\hline MKT Liq. Var. & $\Delta \mathrm{QBAS}$ & $\triangle \mathrm{PQBAS}$ & $\Delta$ EFFS & $\triangle \mathrm{MEFFS}$ & $\Delta \mathrm{HL}$ Spread & $\Delta \mathrm{TOV}$ & $\Delta$ Volume & $\Delta$ Tvalue & $\Delta$ NoTrades \\
\hline \multicolumn{10}{|l|}{ Exp. Var. } \\
\hline Constant & $0.081^{\mathrm{a}}$ & $0.060^{\mathrm{c}}$ & -0.008 & -0.006 & -0.007 & $0.058^{\mathrm{a}}$ & $0.051^{\mathrm{a}}$ & $0.079^{\mathrm{a}}$ & $0.032^{\mathrm{a}}$ \\
\hline $\mathrm{MKT}_{P o s}$ & $-0.133^{\mathrm{a}}$ & $-0.376^{\mathrm{b}}$ & -0.019 & $0.097^{\mathrm{a}}$ & -0.010 & $0.195^{\mathrm{b}}$ & $0.326^{\mathrm{a}}$ & $0.388^{\mathrm{b}}$ & $0.287^{\mathrm{a}}$ \\
\hline $\mathrm{MKT}_{\text {Neg }}$ & $-16.386^{\mathrm{a}}$ & $-25.795^{\mathrm{a}}$ & $1.005^{\mathrm{a}}$ & $1.196^{\mathrm{a}}$ & $3.125^{\mathrm{a}}$ & $4.538^{\mathrm{a}}$ & $4.431^{\mathrm{a}}$ & $3.827^{\mathrm{a}}$ & $1.728^{\mathrm{a}}$ \\
\hline MA5MKT $_{P o s}$ & $9.076^{\mathrm{a}}$ & $9.842^{\mathrm{a}}$ & $-1.136^{\mathrm{a}}$ & $-1.391^{\mathrm{a}}$ & $-2.991^{\mathrm{a}}$ & $-1.369^{\mathrm{c}}$ & -0.843 & $1.814^{\mathrm{c}}$ & -0.044 \\
\hline $\mathrm{MA5MKT}_{N e g}$ & 4.102 & $12.119^{\mathrm{a}}$ & 0.314 & 0.401 & -0.064 & $-2.699^{c}$ & -2.634 & $-4.942^{\mathrm{b}}$ & 0.157 \\
\hline MKTVol & $-8.973^{\mathrm{a}}$ & $-7.787^{\mathrm{a}}$ & $1.093^{\mathrm{a}}$ & $1.274^{\mathrm{a}}$ & $3.122^{\mathrm{a}}$ & 1.184 & 0.662 & $-1.989^{\mathrm{b}}$ & -0.061 \\
\hline Sunday & -0.008 & -0.045 & $0.011^{\mathrm{b}}$ & 0.008 & $0.018^{\mathrm{b}}$ & $-0.051^{\mathrm{a}}$ & $-0.058^{\mathrm{a}}$ & $-0.064^{\mathrm{a}}$ & $-0.036^{\mathrm{a}}$ \\
\hline Monday & -0.019 & -0.031 & 0.008 & 0.008 & $-0.026^{\mathrm{a}}$ & $-0.029^{c}$ & -0.005 & -0.010 & 0.003 \\
\hline Tuesday & $-0.081^{\mathrm{a}}$ & $-0.087^{\mathrm{a}}$ & 0.006 & $0.012^{\mathrm{b}}$ & $0.030^{\mathrm{a}}$ & -0.008 & -0.013 & -0.007 & -0.004 \\
\hline Wednesday & -0.032 & -0.001 & 0.008 & 0.006 & 0.005 & $-0.039^{b}$ & $-0.032^{\mathrm{c}}$ & -0.026 & $-0.015^{\mathrm{c}}$ \\
\hline February & 0.036 & $0.071^{\mathrm{b}}$ & 0.000 & -0.001 & 0.006 & -0.003 & 0.014 & -0.005 & -0.006 \\
\hline March & $0.044^{\mathrm{c}}$ & 0.048 & 0.006 & 0.001 & -0.002 & 0.005 & 0.017 & 0.018 & 0.005 \\
\hline April & $0.040^{\mathrm{c}}$ & 0.034 & 0.006 & 0.004 & 0.010 & 0.013 & 0.005 & -0.011 & -0.007 \\
\hline May & 0.028 & 0.025 & -0.001 & -0.002 & 0.003 & 0.013 & 0.015 & 0.016 & -0.003 \\
\hline June & 0.032 & $0.062^{\mathrm{c}}$ & 0.005 & 0.002 & 0.010 & 0.003 & 0.006 & -0.013 & -0.005 \\
\hline July & 0.002 & 0.049 & 0.005 & 0.004 & 0.001 & 0.002 & 0.019 & 0.002 & 0.000 \\
\hline August & 0.013 & 0.047 & 0.009 & 0.009 & 0.010 & 0.008 & 0.010 & -0.013 & -0.006 \\
\hline September & $0.040^{c}$ & 0.030 & 0.006 & 0.002 & 0.004 & 0.005 & 0.015 & 0.002 & -0.004 \\
\hline October & $0.038^{c}$ & $0.062^{\mathrm{c}}$ & 0.006 & 0.007 & 0.005 & 0.009 & 0.020 & 0.006 & -0.004 \\
\hline November & 0.020 & 0.042 & 0.003 & 0.000 & 0.008 & -0.001 & 0.012 & 0.004 & -0.014 \\
\hline December & $0.077^{\mathrm{a}}$ & $0.075^{\mathrm{b}}$ & 0.007 & 0.002 & -0.002 & 0.001 & 0.024 & 0.004 & -0.010 \\
\hline$R^{2}$ & 0.047 & 0.084 & 0.006 & 0.008 & 0.034 & 0.016 & 0.016 & 0.015 & 0.019 \\
\hline Adj $R^{2}$ & 0.041 & 0.078 & 0.001 & 0.002 & 0.029 & 0.010 & 0.010 & 0.009 & 0.014 \\
\hline
\end{tabular}

Note. This table reports the results of the time-series regression equation (8). The dependent variables are the daily changes in market liquidity, which are described in Table $1 . \Delta$ refers to the daily percentage change in market liquidity. The explanatory variables include the following: $\mathrm{MKT}_{P o s}\left(\mathrm{MKT}_{\text {Neg }}\right.$ ) refers to up (down) markets, which is the daily market return if it is positive (negative) and zero otherwise; $\mathrm{MA5MKT}_{P o s}\left(\mathrm{MA5MKT}_{\mathrm{Neg}}\right.$ ) refers to recent rising (falling) market movements, which is the daily market return over the past five trading days if it is positive (negative) and zero otherwise; MKTVol refers to market volatility measured as the average of the absolute value of the daily market return over the past five trading days. Sunday to Wednesday is the day-of-the-week dummy that takes the value 1 if the trading day is Sunday, Monday, Tuesday, Wednesday, respectively, and zero otherwise. February to December is the month of the year dummy that takes the value of 1 if the trading day falls in one of these eleven months and zero otherwise. MKT Liq. Var. refers to market liquidity variables. Exp. Var. refers to explanatory variables. $R^{2}$, Adj $R^{2}$ is the R-squared and the adjusted R-squared, respectively. a, b, and c refer to significance level at $1 \%, 5 \%$, and $10 \%$, respectively. Numbers written in boldface indicate a marginal significance at $10 \%$ level of significance.

\section{Conclusion}

A few studies on developed markets have focused on market liquidity. However, studies that have examined the determinants of market liquidity over a long time period for emerging markets are virtually nonexistent. This paper, therefore, investigates the factors that affect daily variations in market liquidity and analyzes its time-series behavior for ASE over a 15-year period that extends from January 2000 to December 2014. Market liquidity is measured using nine measures of liquidity, which are defined first at firm-level and then cross-sectionally averaged in each trading day to construct market liquidity series. Using the method of Chordia et al. (2001), the majority of empirical results of time-series regressions show that there is an asymmetric response of market liquidity to concurrent market movements. Market liquidity increases in up markets while it decreases in down markets. More specifically, both quoted spread and proportional quoted spread decrease (increase) during up (down) market conditions, and the opposite is true for trading activity measures; they increase and decrease, respectively in up and down market conditions. However, the results of effective spread measures and HL spread show inconsistent results.

Market liquidity is also related to recent market movements, recently rising and falling markets. A recently rising market is related to an increase in both quoted and proportional quoted spread, which is unexpected, but it is 
related to a decrease in effective spread measures and HL spread. On the other hand, market liquidity increases following a recently falling market; there is a decrease in proportional quoted bid-ask spread and an increase in turnover rate and trading value. Further, recent market volatility tends to affect market liquidity, which shows inconsistent response to market volatility. As expected, market liquidity decreases with volatility as shown by the estimated coefficient of market volatility, which is significantly positive in effective spread, modified effective spread and HL spread regressions and negative in trading value regression. In contrast, the results of quoted spread and proportional quoted spread regressions show that market liquidity increases with market volatility. Furthermore, the results show that there is a distinctive weekly and monthly regularity in market liquidity. There is a significant drop in market liquidity on Sunday, while the behavior of market liquidity at the end of the week is inconclusive; market liquidity increases (decreases) as indicated in trading activity (spread) measures. Finally, market liquidity drops significantly in December and February as shown by the results of both quoted spread and proportional quoted spread. In contrast, the results of trading activity measures show an increase in market liquidity during January relative to other months; the constant that is picking up the effect of January is significantly positive in all trading activity regressions.

\section{References}

Acharya, V., \& Pedersen, L. (2005). Asset pricing with liquidity risk. Journal of Financial Economics, 77, 375-410. http://dx.doi.org/10.1016/j.jfineco.2004.06.007

Amihud, Y. (2002). Illiquidity and stock returns: Cross-section and time-series effect. Journal of Financial Markets, 5, 31-56. http://dx.doi.org/10.1016/S1386-4181(01)00024-6

Bali, T. G., Peng, L., Shen, Y., \& Tang, Y. (2014). Liquidity Shocks and Stock Market Reactions. Review of Financial Studies, 27, 1434-1485. http://dx.doi.org/10.1093/rfs/hht074

Bekaert, G., Harvey, C. R., \& Lundblad, C. (2007). Liquidity and Expected Returns: Lessons from Emerging Markets. Review of Financial Studies, 20, 1783-1831. http://dx.doi.org/10.1093/rfs/hhm030

Benston, G. J., \& Hagerman, R.L. (1974). Determinants of bid-asked spreads in the over-the-counter market. Journal of Financial Economics, 1, 353-364. http://dx.doi.org/10.1016/0304-405X(74)90014-2

Branch, B., \& Freed, W. (1977). Bid-Asked Spreads on the AMEX and the Big Board. The Journal of Finance, 32, 159-163. http://dx.doi.org/10.1111/j.1540-6261.1977.tb03249.x

Chen, J. (2005). Pervasive Liquidity Risk And Asset Pricing. Job Market Paper, Columbia University, pp. 1-43.

Chordia, T., Roll, R., \& Subrahmanyam, A. (2000). Commonality in liquidity. Journal of Financial Economics, 56, 3-28. http://dx.doi.org/10.1016/S0304-405X(99)00057-4

Chordia, T., Roll, R., \& Subrahmanyam, A. (2001). Market Liquidity and Trading Activity. Journal of Finance, 56, 501-530. http://dx.doi.org/10.1111/0022-1082.00335

Chordia, T., Roll, R., \& Subrahmanyam, A. (2002). Order imbalance, liquidity, and market returns. Journal of Financial Economics, 65, 111-130. http://dx.doi.org/10.1016/S0304-405X(02)00136-8

Chordia, T., Sarka , A., \& Subrahmanyam, A. (2005). An Empirical Analysis of Stock and Bond Market Liquidity. The Review of Financial Studies, 18, 85-129. http://dx.doi.org/10.1093/rfs/hhi010

Comerton-Forde, C., Hendershott, T., Jones, C. M., Moulton, P. C., \& Seasholes, M. S. (2010). Time Variation in Liquidity: The Role of Market-Maker Inventories and Revenues. The Journal of Finance, 65, 295-331. http://dx.doi.org/10.1111/j.1540-6261.2009.01530.x

Corwin, S. A., \& Schultz, P. (2012). A Simple Way to Estimate Bid-Ask Spreads from Daily High and Low Prices. The Journal of Finance, 67, 719-760. http://dx.doi.org/10.1111/j.1540-6261.2012.01729.x

Datar, V. T., Naik, N. Y., \& Radcliffe, R. (1998). Liquidity and stock returns: An alternative test. Journal of Financial Markets, 1, 203-219. http://dx.doi.org/10.1016/S1386-4181(97)00004-9

Demsetz, H. (1968). The cost of transacting. Quarterly Journal of Economics, 82, 33-53. http://dx.doi.org/10.2307/1882244

Easley, D., Kiefer, N. M., O'Hara, M., \& Paperman, J. B. (1996). Liquidity. Information, and Infrequently Traded Stocks. Journal of Finance, 51, 1405-1436. http://dx.doi.org/10.1111/j.1540-6261.1996.tb04074.x

Fujimoto, A. (2003). Macroeconomic Sources of Systematic Liquidity. Working Paper, Yale University, pp. $1-50$.

Gervais, S., \& Odean, T. (2001). Learning to be overconfident. Rev. Financ. Stud., 14, 1-27. 
http://dx.doi.org/10.1093/rfs/14.1.1

Glaser, M., \& Weber, M. (2009). Which past returns affect trading volume? Journal of Financial Markets, 12, 1-31. http://dx.doi.org/10.1016/j.finmar.2008.03.001

Goyenko, R. Y., \& Ukhov, A. D. (2009). Stock and Bond Market Liquidity: A Long-Run Empirical Analysis. Journal of Financial and Quantitative Analysis, 44, 189-212. http://dx.doi.org/10.1017/S0022109009090097

Goyenko, R. Y., Holden, C. W., \& Trzcinka, C. A. (2009). Do liquidity measures measure liquidity? Journal of Financial Economics, 92, 153-181. http://dx.doi.org/10.1016/j.jfineco.2008.06.002

Hasbrouck, J., \& Seppi, D. J. (2001). Common factors in prices, order flows, and liquidity. Journal of Financial Economics, 59, 383-411. http://dx.doi.org/10.1016/S0304-405X(00)00091-X

Huberman, G., \& Halka, D. (2001). Systematic liquidity. The Journal of Financial Research, 24, $161-178$. http://dx.doi.org/10.1111/j.1475-6803.2001.tb00763.x

Korajczyk, R. A., \& Sadka, R. (2008). Pricing the commonality across alternative measures of liquidity. Journal of Financial Economics, 87, 45-72. http://dx.doi.org/10.1016/j.jfineco.2006.12.003

Lagoarde-Segot, T., \& Lucey, B. M. (2008). Efficiency in emerging markets-Evidence from the MENA region. Journal of International Financial Markets, Institutions and Money, 18, 94-105. http://dx.doi.org/10.1016/j.intfin.2006.06.003

Lesmond, D. (2005). Liquidity of emerging markets. Journal of Financial Economics, 77, 411-452. http://dx.doi.org/10.1016/j.jfineco.2004.01.005

Martínez, M. A., Nieto, B., Rubio, G., \& Tapia, M. (2005). Asset pricing and systematic liquidity risk: An empirical investigation of the Spanish stock market. International Review of Economics \& Finance, 14, 81-103. http://dx.doi.org/10.1016/j.iref.2003.12.001

Menyah, K., \& Paudyal, K. (1996). The determinants and dynamics of bid-ask spreads on the london stock exchange. Journal of Financial Research, $19, \quad 377-394$. http://dx.doi.org/10.1111/j.1475-6803.1996.tb00220.x

Narayan, K. P., Zhang, Z., \& Zheng, X. (2011). Some Hypotheses on Commonality in Liquidity: New Evidence from the Chinese Stock Market. School Working Paper, School of Accounting, Economics and Finance, Deakin University.

Pastor, L., \& Stambaugh, R. F. (2003). Liquidity risk and expected stock returns. The Journal of Political Economy, 111, 642-685. http://dx.doi.org/10.1086/374184

Pukthuanthong-Le, K., \& Visaltanachoti, N. (2009). Commonality in liquidity: Evidence from the Stock Exchange of Thailand. Pacific-Basin Finance Journal, $17, \quad 80-99$. http://dx.doi.org/10.1016/j.pacfin.2007.12.004

Roll, R. (1984). A Simple Implicit Measure of the Effective Bid-Ask Spread in an Efficient Market. The Journal of Finance, 39, 1127-1139. http://dx.doi.org/10.2307/2327617

Statman, M., Thorley, S., \& Vorkink, K. (2006). Investor Overconfidence and Trading Volume. Review of Financial Studies, 19, 1531-1565. http://dx.doi.org/10.1093/rfs/hhj032

Stoll, H. R. (1978). The Pricing of Security Dealer Services: An Empirical Study of Nasdaq Stocks. The Journal of Finance, 33, 1153-1172. http://dx.doi.org/10.1111/j.1540-6261.1978.tb02054.x

Syamala, S. R., Reddy, V. N., \& Goyal, A. (2014). Commonality in liquidity: An empirical examination of emerging order-driven equity and derivatives market. Journal of International Financial Markets, Institutions and Money, 33, 317-334. http://dx.doi.org/10.1016/j.intfin.2014.09.001

Tayeh, M. (2016). Commonality in Liquidity in the Context of Different Trading Systems: Evidence from an Emerging Market. International Journal of Economics and Financial Issues, forthcoming.

Tayeh, M. I. D. (2010). A Comparative Analysis of the Determinants and Pricing of Liquidity in Floor and Electronic Trading Systems (Doctoral thesis, Durham University, pp. 1-325). Retrieved from http://etheses.dur.ac.uk/333/

Tayeh, M., Bino, A., Ghunmi, D. A., \& Tayem, G. (2015). Liquidity Commonality in an Emerging Market: Evidence from the Amman Stock Exchange. International Journal of Economics and Finance, 7, $203-213$. http://dx.doi.org/10.5539/ijef.v7n2p203 
Tinic, S. M. (1972). The economics of liquidity services. Quarterly Journal of Economics, 86, 79-93. http://dx.doi.org/10.2307/1880494

Van Ness, B. F., Van Ness, R. A., \& Warr, R. S. (2005). Nasdaq Trading and Trading Costs: 1993-2002. The Financial Review, 40, 281-304. http://dx.doi.org/10.1111/j.1540-6288.2005.00103.x

\section{Notes}

Note 1. Studies that examine the commonality in liquidity in emerging markets include Pukthuanthong-Le and Visaltanachoti (2009), Narayan et al. (2011), Syamala et al. (2014), Tayeh et al. (2015) and Tayeh (2016).

Note 2. Studies in this area include, for example, Amihud (2002), Pastor and Stambaugh (2003), Acharya and Pedersen (2005), Martínez et al. (2005), Korajczyk and Sadka (2008) among others.

Note 3. The exchange rate $\$ / J D 0.7$, which is a fixed rate against the dollar, is used to perform the comparison.

Note 4. Augmented Dickey-Fuller and Phillips-Perron tests have been applied to test for stationarity (i.e. unit root test). The results of the test show that no series included in the analysis have a unit root; they are all stationary. However, to save some space, the results of unit root tests are not reported.

\section{Copyrights}

Copyright for this article is retained by the author(s), with first publication rights granted to the journal.

This is an open-access article distributed under the terms and conditions of the Creative Commons Attribution license (http://creativecommons.org/licenses/by/4.0/). 